Journal of Contemporary African Studies

\title{
Transitions to democracy, institutional choices and party system stability: lessons from small African islands
}

\section{Edalina Rodrigues Sanches}

To cite this article: Edalina Rodrigues Sanches (2020): Transitions to democracy, institutional choices and party system stability: lessons from small African islands, Journal of Contemporary African Studies, DOI: 10.1080/02589001.2020.1774048

To link to this article: https://doi.org/10.1080/02589001.2020.1774048

\section{曲 Published online: 01 Jun 2020.}

Submit your article to this journal 전

Џ Article views: 31

Q View related articles ¿

View Crossmark data \lceil 


\title{
Transitions to democracy, institutional choices and party system stability: lessons from small African islands
}

\author{
Edalina Rodrigues Sanches \\ ICS, Instituto de Ciências Sociais da Universidade de Lisboa, Lisbon, Portugal
}

\begin{abstract}
It is not easy to understand why some African party systems manage to stabilise while others remain fluid. This article argues that institutional choices made during democratic transition impact the likelihood of party system stabilisation. The experiences of Cabo Verde, Comoros, São Tomé and Príncipe and Seychelles are compared; despite sharing many similarities (insularity, smallness, low ethnic diversity, authoritarian past, economic vulnerability and competitive elections), they differ substantively in terms of the patterns of interparty competition. It is shown that stabilisation is likely if party elites are able to control the rules of the game during the transition to democracy. A strategic choice of the party law, electoral system and executive system helps structure interactions over time and reduce uncertainty in electoral competition. The findings highlight the need to further explore the 'black box' of democratic transitions, and the role of agency in political outcomes in Africa.
\end{abstract}

\section{ARTICLE HISTORY}

Received 26 April 2017

Accepted 21 May 2020

\section{KEYWORDS}

Party systems; stability; small African islands; democratic transitions; institutional choices

\section{Introduction}

Over a quarter century has elapsed since the third wave of democracy spread to subSaharan Africa. In most countries, multiparty elections are now the regular procedure for electing the government, even when significant problems of integrity arise (Norris and Grömping 2019). Party systems emerging from these elections vary considerably in terms of the degree of stabilisation or institutionalisation (Kuenzi and Lambright 2001; Basedau 2007; Lindberg 2007; Ferree 2010; Riedl 2014; Weghorst and Bernhard 2014; Kuenzi et al. 2017; Sanches 2018).

The most compelling explanations for this variation emphasise the long-term impact of authoritarian legacies (LeBas 2011; Riedl 2014) and the structure of social cleavages and ethnic coalitions (Ferree 2010; Weghorst and Bernhard 2014). While political institutions seem to be less influential (Ferree 2010; Riedl 2014), some findings should be noted. Proportional representation (PR) formulas and presidentialism tend to produce higher levels of institutionalisation (Weghorst and Bernhard 2014; Sanches 2018), as do stricter rules on party switching (Goeke and Hartmann 2011) and access to public funding (Sanches 2018). Although these studies shed light on the effects of political institutions on party system 
development, the question of why certain institutions are chosen over others remains under-researched.

This article argues that institutional choices made during democratic transition impact party systems stabilisation over time. Democratic 'transitions are delimited, on the one side, by the launching of the process of dissolution of an authoritarian regime and, on the other, by the installation of some form of democracy' ( $\mathrm{O}^{\prime}$ Donnell and Schmitter $1986,6)$. They therefore represent a critical juncture of party formation and institutional crafting during which party elites seek to minimise the odds of losing power (Colomer 2001). The choices made at this point will influence the kind of competition that will emerge in the future, even if they are confronted with high levels of uncertainty (Lupu and Riedl 2013, 1344).

Politics in Africa is often defined in terms of informal institutions but many studies have demonstrated the key role played by party laws, electoral systems and executive systems in electoral competition (van Cranenburgh 2003; Lindberg 2005; Salih and Nordlund 2007; Goeke and Hartmann 2011). Adding to these findings, this study argues that, when choosing institutions, party elites try to anticipate some of their effects by selecting those that best protect their interests.

These arguments are tested through an in-depth comparative study of four cases Cabo Verde, Comoros, São Tomé and Príncipe and Seychelles; despite some similarities (insularity, smallness, low ethnic diversity, authoritarian past, economic vulnerability, competitive elections), their patterns of interparty competition differ substantively (more stable in Cabo Verde and Seychelles and more fluid in Comoros and São Tomé and Príncipe). Arguably, different sets of contextual, contigent and structural factors affect party system development (Riedl 2014; Weghorst and Bernhard 2014; Sanches 2018), but focusing on most similar cases, while keeping extraneous variance constant, reveals the importance of institutional choices made during transition. Thus, the empirical analysis starts by depicting the choices made during transition, before discussing how the choices structured competition over time.

The analysis follows the logic of descriptive inference since it seeks to demonstrate the existence of links between choices and effects, focusing on strategic institutional choices as key causal mechanisms. The study contributes to the theory of party system development by highlighting the relevance of transitions and party elite agency. The literature on small state politics is also advanced by showing that politics is not always beautiful in smaller jurisdictions (Anckar 2008). The variations in constitutional and institutional design in small states (Poupko 2017) can further our understanding of politics in larger states (Veenendaal and Corbett 2015).

The article starts with a literature review on party system development in Africa and discusses why institutional choices made during transition to democracy matter. The rationale of case selection is then explained before describing the degree of stability of each party system. The main empirical section characterises the context of democratic transition and how party elites selected party laws, electoral systems and the system of government. A discussion of the differences and commonalities across cases follows to shed more light on the link between choices and consequences. The final section summarises the main findings and sets out the implications for further research on party system development in Africa. 


\section{Understanding party systems in Africa: why democratic transitions still matter?}

Party systems are the system of interactions resulting from interparty competition (Sartori 1976) but there is little consensus on which indicators best describe these interactions. Scholars have gone from counting the number of relevant parties (Laakso and Taagepera 1979; Duverger 1959), to trying to measure the degree to which party systems are institutionalised (Mainwaring and Scully 1995). Institutionalisation and its dimensions have been measured variously in studies spanning all regions in the world, but stability has come to be considered its most relevant dimension (Casal Bértoa 2018; Mainwaring 2018). It expresses the extent to which a stable set of parties interact in relatively stable ways over time (Mainwaring 2018).

African party systems have been classified in terms of the number of relevant parties (Bogaards 2004; Salih and Nordlund 2007), the degree of institutionalisation (Kuenzi and Lambright 2001; Basedau 2007; Osei 2013; Riedl 2014; Sanches 2018) and stability (Lindberg 2007; Ferree 2010; Weghorst and Bernhard 2014; Kuenzi et al. 2017). These studies all show a striking variation in the level of stability or institutionalisation of party systems, with countries like Botswana, Cabo Verde, Namibia and South Africa displaying higher levels of stability and rootedness in society than Zambia, Comoros or Benin, for example.

A handful of studies have investigated the sources of this variation. Ferree (2010) demonstrated that instability increased when no ethnic group was able to form a minimum winning coalition (MWC). Riedl (2014) argued that the incumbent's control over the transition process mattered more for party system institutionalisation than colonial background, type of electoral system, state of the economy or the strength of social cleavages. Following Ferree (2010), Weghorst and Bernhard (2014) confirmed that MWC decreased levels of stability, and this was also the case in former French colonies and countries where the colonisation had come to an end sooner. My recent work highlights factors related to both path-dependency (transition mode) and agency (strategic choice of institutions and party building strategies) to explain variation in levels of institutionalisation (Sanches 2018).

The role of political institutions is less obvious. Contrary to conventional wisdom (van de Walle 2003), presidentialism appears to have little (Ferree 2010) or no effect on institutionalisation (Weghorst and Bernhard 2014); and 'greater proportionality increases volatility rather than reducing it as it does in many other regions.' (Weghorst and Bernhard 2014, 1730). In contrast, anti-defection laws (Goeke and Hartmann 2011), provision of public funding, and programmatic linkages favour institutionalisation (Sanches 2018).

Within this literature, not much is known about why party elites choose one type of institution over the other, particularly during critical junctures such as the transitions to democracy. But exploring this context further sheds light on electoral competition in Africa. First, critical junctures produce 'overwhelming mandates for policy and/or structural change' and 'are seen as resulting in the adoption of a particular institutional arrangement from amongst alternatives' (Hogan and Doyle 2009, 4). Therefore, they 'set the tone for what comes in their wake' (Ibid.). The transition stage is often seen as a critical juncture as it 'coincides with the breaking of the previous power monopoly and with the formative period for the new political movements'; therefore, we can expect 'that it will have a 
significant impact in shaping the new parties (party unit level) and relations among parties (party system level)' (Cotta 1996, 73). Second, political institutions set the rules of the game and, as such, create incentives for political actors to preserve rules that are beneficial to them or alter those which are unfavourable (Colomer 2001). Even when confronted with high levels of uncertainty (Lupu and Riedl 2013), party elites make strategic decisions on the basis of the available information.

In most African countries, transition to multipartyism opened a window of opportunity for institutional crafting. The broad spectrum of variation in party laws ranges from more restrictive laws - that proscribe political parties and protect the interests of existing parties - to more permissive laws - that set minimal requirements for party activities and seek to promote representation (Salih and Nordlund 2007, 103-119). Party elites can also choose the electoral rules that will increase their chances of being elected. It has been shown that political configurations dominated by few parties are inclined to establish majority rules, which 'tend to produce a single, absolute winner and subsequent absolute losers', whereas multiparty systems are more likely to opt for proportional representation systems which in principle 'create multiple partial winners and far fewer total losers than majority rules' (Colomer 2005, 2). Besides the electoral formula, other elements such as assembly size, district magnitude, ballot structure and electoral thresholds, can influence the degree of proportionality of an election, how many parties are elected and the likelihood of single party governments (Lijphart 1994).

Finally, the choice of the executive system is critical for cabinet formation and stability. In presidential systems, a strong executive power, with full control of cabinet composition, is elected for a fixed term and is independent of parliamentary votes of confidence and can only be removed in extreme circumstances (Linz 1990). The party that elects the president is in a winner-takes-all situation. This contrasts with parliamentary systems where the parliament is the sole elected institution and the government needs parliamentary confidence (Linz 1990); and with semi-presidentialism where the president is directly elected for a fixed term and a prime minister and a cabinet are collectively accountable to the legislature (Elgie 2011). This means that, under parliamentary and semi-presidential systems, cabinet survival requires negotiation with (and legitimation by) the parliament, which can be particularly challenging in more fluid party systems.

\section{Case selection and research strategy}

The study employs a most similar systems research design incorporating four cases - Cabo Verde, Comoros, São Tomé and Príncipe and Seychelles - with many shared characteristics. First, they are all small island states with less than 1 million inhabitants in relatively homogeneous societies (Schaefer 2008; Ojo 2016). Second, insularity and small size combine to make their economies more vulnerable than larger states (Briguglio et al. 2005). Third, they experienced authoritarianism from the start of independence until the early 1990s. In Cabo Verde, São Tomé and Príncipe and Seychelles, the main anticolonial movements - respectively, Partido Africano da Independência de Cabo Verde (PAICV), Movimento de Libertação de São Tomé e Príncipe (MLSTP) and Seychelles People's Progressive Front (SPPF) - became the country's sole directing force shortly after independence (Fleischhacker 1999; Thibaut 1999b; Clemente-Kersten 1999). In the Comoros, there were five small political parties when independence was announced, but the Union 
Comorienne pour le Progrès (UCP, or Udzima) managed to restrict other parties' activities to become the sole legal party (Banks, Muller, and Overstreet 2007, 205; Hassan 2009, 231). Fourth, by the end of the 1980s the four islands embarked on liberalisation reforms in response to the economic crisis, high levels of popular protest (Comoros), and pressures from regime reformers (Cabo Verde, São Tomé and Príncipe and Seychelles) and the international community. Fifth, they hold elections regularly and have nominally democratic political systems despite varying degrees of quality and of political stability. ${ }^{1}$ Comoros and Seychelles are ranked electoral democracies by the Freedom House, while Cabo Verde and São Tomé and Príncipe stand as liberal democracies. All have sufficient democratic credentials to enable the comparative study of their party systems (on this see Casal Bértoa 2018; Mainwaring 2018). Despite their many similarities, the party systems in these countries have unfolded in distinct ways. As later shown, patterns of interparty competition have been more stable in Cabo Verde and Seychelles than in São Tomé and Príncipe and Comoros.

The purpose of this study is to trace the origins of these different trajectories through a Small-N comparative design that allows the in-depth analysis of the institutional choices made during the transition, and off their effects on party system development. By selecting most similar cases, other potential explanatory factors (e.g. social cleavages, economy, authoritarian past), which are kept constant, can be discarded, while focusing on the variable of interest (institutional choice). ${ }^{2}$ The study seeks not only to explore the characteristics of individual cases but also to identify some regularities across cases, thus contributing to the theories of party system development in Africa.

\section{Party system stability in four small African islands}

Three indicators are employed to characterise party system stability: electoral volatility, seat volatility and alternation in power. Electoral volatility is the vote difference between parties in successive elections divided by two (Pedersen 1983); the same logic is applied to seat volatility. Alternation in power measures whether there has been wholesale, partial, or no-alternation in power (Mair 1996). Altogether these indicators measure stability at the electoral, parliamentary and governing level. More refined measures such as the degree of closure of party systems (Casal Bértoa and Enyedi 2016) were not calculated due to lack data, and electoral volatility in the Comoros was not estimated for the same reason.

Figures 1 and 2 display the selected indicators of stability, and show a broad range of variation across countries and over time. Cabo Verde and Seychelles (particularly between 1998 and 2007) exhibit the lowest rates of volatility, and relatively closed structures of competition.

In Seychelles, the structure of competition was predictable until 2016: the SPPF, renamed Parti Lepep (PL) in 2009, won the majority of parliamentary seats in all polls, with seat gains varying between 67.6\% (in 2002 and 2007) and 97.1\% (in 2011). However, in 2016 the country witnessed the first ever alternation in power, with the coalition Linyon Demokratik Seselwa (LDS) winning 57.6\% of the seats vis-à-vis SPPF/PL's 42.4\%. Apart from LDS, only one other party gained parliamentary representation between 1993-2016 - the Popular Democratic Movement (PDM) in 2011. 


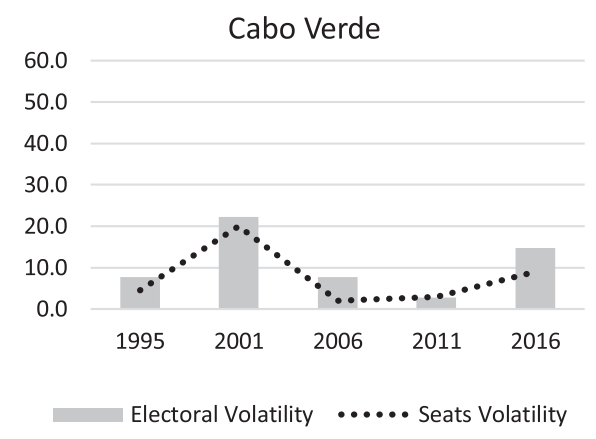

São Tomé and Príncipe

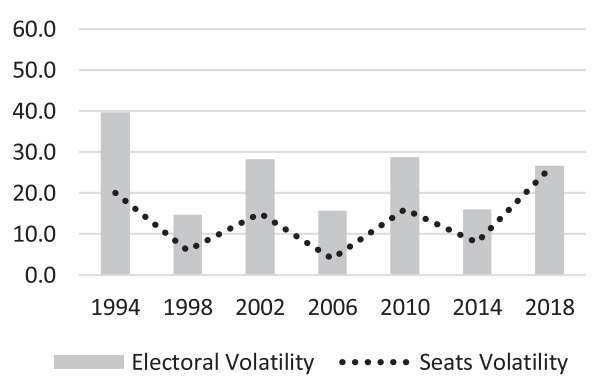

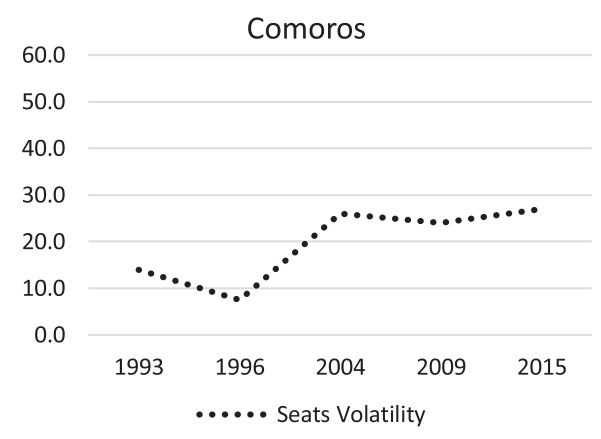

Seychelles

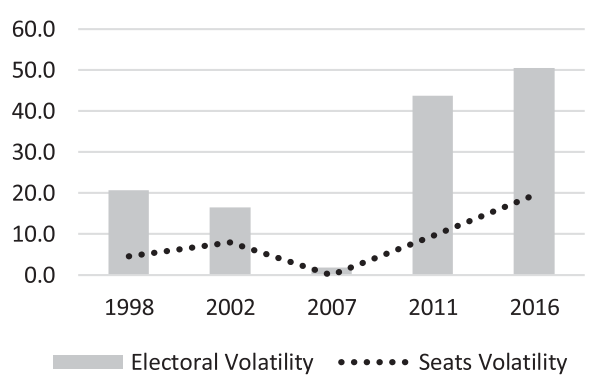

Figure 1. Indicators of Party system stability: electoral volatility and Seat Volatility. Source: Author's elaboration.

Cabo Verde has a classical two-party system in which two parties have a more or less equal chance of winning sufficient electoral support to gain an executive monopoly. Unlike the Seychelles, alternation occurred in half of the elections (1991; 2001 and 2016). The PAICV and the Movimento para a Democracia (MpD) are the

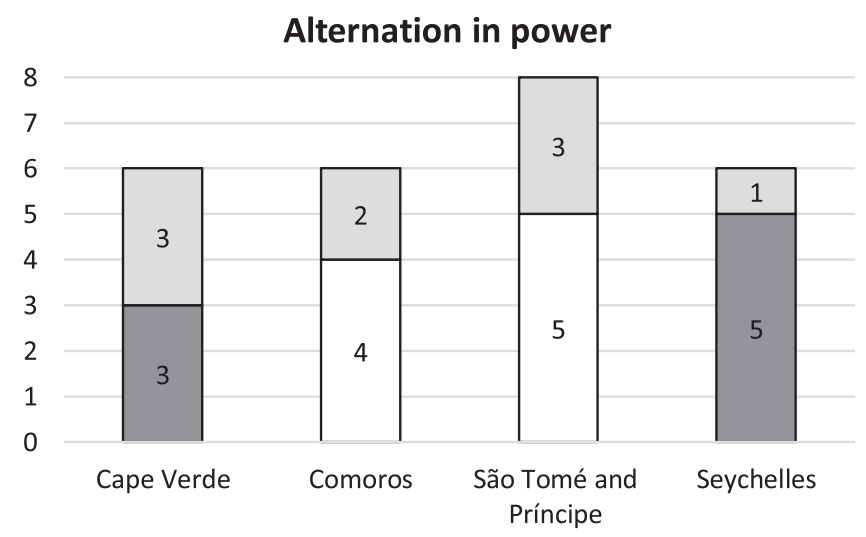

$\square$ Non Alternation $\quad \square$ Partial $\square$ Wholesale

Figure 2. Indicators of Party system stability: patterns of alternation in government. Source: Author's elaboration. 
most important parties in the system: together, they hold more than $95 \%$ of the seats in parliament leaving only a narrow margin of eligibility to smaller parties. Both parties have been able to form single-party cabinets with wide parliamentary support (PAICV in 2001, 2006 and 2011; MpD in 1991, 1995 and 2016). So far, only three small parties have reached parliament: the Partido da Convergência Democrática (PCD) in 1995, the Partido Social Democrático (PSD) in 2001 and the União Caboverdiana Independente e Democrática (UCID) in 2006.

São Tomé and Príncipe is a multiparty system comprising four relevant parties/ coalitions which succeeded each other in power: 1) the Partido de Convergência Democrática-Grupo de Reflexão (PCD-GR), winner of the founding multiparty elections in 1991, 2) the MLSTP/PSD ${ }^{3}$, most voted party between 1994 and 2002; 3) the coalition between Movimento Democrático das Forças da Mudança-Partido Liberal and PCD-GR (MDFM-PCD), which won the 2006 elections; and finally 4) the Acção Democrática Independente (ADI) most voted party in 2010, 2014 and 2018. Generally speaking, these parties are described as personalistic vehicles for endorsing presidential candidates and the product of 'factionist struggles and personal rivalries' (Seibert 2016, 3). Overall, Santomean elections are more competitive and unpredictable and result in more fragmented parliaments and short lived cabinets (Seibert 2016; Sanches 2017).

In Comoros, no single party has ever secured a majority following elections. Parties frequently change labels, merge and split between elections. In 1992, Union des Démocrates pour le Développement (UDD) received the largest share of seats (7 out 36) while 14 parties and independents took the remaining seats. In 1993, the Rassemblement pour la Démocratie et le Renouveau (RDR), a merger of several parties including the incumbent UDD, won the qualified majority of seats but seven other parties still reached the parliament. In 1996, the Rassemblement National pour le Développement (RND), established through the merger of the incumbent RDR and several other parties, won almost all the parliamentary seats. The Camp des illes Autonomes (CdIA), an alliance including several parties and the former ruling party RND, gained the most votes in 2004 but saw the Baobab Coalition, which supported President Ahmed Abdallah Sambi, win the 2009 elections. Finally, the alliance between Union pour le Développement des Comores (UPDC) and the Parti Juwa (PJ) won $33 \%$ and $29.2 \%$ of seats respectively in 2015 .

Overall, these indicators point to higher levels of stability in Cabo Verde and, to some extent, in Seychelles than in Comoros and São Tomé and Príncipe. The former two are characterised by lower levels of volatility in most elections, less permeability of new parties, and fewer episodes of alternation in power. The following section explains these different trajectories by focusing on the institutional choices made during the transition.

\section{The road to party system stability: exploring the impact of the choices made during democratic transition}

\subsection{Cabo verde}

Cabo Verde's democratic transition was initiated by the regime but eventually involved a pact between the elites of the authoritarian regime (PAICV) and the new opposition elites (MpD). From 1985 and until the appearance of MpD in March 1990, the PAICV launched a 
series of reforms. This included the approval of a new electoral law that allowed independent candidates to run in the 1985 elections, and the establishment of a broad reforming agenda during the 1988 party congress held under the motto 'A party for the future in a changing world'. However, these reforms were unable to mitigate the pressures for political opening, particularly when the MpD appeared on the scene. At that point, the PAICV began a rapid process of liberalisation with the aim of gaining an advantage over the opponents and preventing the MpD from becoming more organised; however, this proved unsuccessful. The MpD emerged as a strong negotiator at this stage, and conditioned the liberalisation agenda thanks to the PAICV's overconfidence that it would win the founding elections (Sanches 2017, 2018).

The party law (Law 86/1II/90) was published just three months before the January 1991 elections, which meant that political organisations had little time to submit their application. Registering a party entailed meeting the following requirements: at least 500 members, 10 of whom had to reside in one of the country's councils; founding constitution, approved programmes and statutes, members' criminal records and residency terms (Article 6.1). The party law included bans on religious and local parties, rules for funding on the basis of the number of legislators elected (Article 19), and it instituted fiscal rights for parties acquiring at least $5 \%$ of the votes. The late approval of the law and the strictness of the regulations eventually protected the PAICV and MpD from further competition. In fact, two political parties operating outside of the country were unable to meet the legal requirements in due time to participate in 1991 elections (Sanches 2017, 2018). ${ }^{4}$

The PAICV and MpD were also strategic about the choice of the electoral system for the parliamentary elections (Law 81/III/90): both agreed on a PR system but had different motivations. The PAICV was used to this formula, and changing it could imply higher risks. The MpD did not expect to win the elections but only to get one third of the seats (Sanches 2018). In theory, PR systems favour representation particularly in larger electoral districts. However, the law stipulates that the majority of the electoral districts (12 out of 19) elect fewer than 4 mandates; and this benefits the major parties as they have more chance of getting the few potential seats. This choice is instrumental and confirms the expectation that large parties often prefer districts to be smaller in order to exclude others from competition (Colomer 2005, 3). During the transition, the presidential elections were seen as a more influential determinant of who would govern. The PAICV hoped to capitalise on the charisma of the incumbent President Aristides Pereira ${ }^{5}$ by holding the presidential elections prior to legislative elections; but the MpD wanted the opposite and eventually managed to alter the election calendar accordingly.

Finally, the choice for the executive system was another source of contention. While both PAICV and MpD agreed on a semi-presidential regime, they diverged on the extent of presidential powers. The MpD preferred a 'mitigated form of parliamentarianism' in which the prime minister and the parliament had greater powers regarding cabinet formation and dismissal (Costa 2001). The underlying motivations were clear: while PAICV expected to re-elect Aristides Pereira and wanted a stronger president, the MpD still wanted to have a say as a parliamentarian force. However, the decision on these rules was postponed until after the polls due to the lack of agreement. 


\subsection{Comoros}

Since it gained independence, the Comoros has experienced continuous political instability triggered by inter-island rivalries over the structure of the executive system and the economic, fiscal and political autonomy of the islands (Hassan 2009; Baker 2008). Talks for political liberalisation started after President Ahmed Abdallah's assassination in 1989, following a constitutional referendum that approved the extension of the presidential term and reinstated the post of prime minister. Said Mohamed Djohar was subsequently appointed interim President and stated his 'willingness to enter into a pact of reconciliation with his opponents, on condition that they did not challenge the legitimacy of his incumbency or attempt to destabilise the regime' (Banks, Muller, and Overstreet 2007, 207). The opposition demanded the establishment of a 'transitional government of national unity and a round table for drafting the new constitution' but these demands were not met (Thibaut 1999a, 243-244).

Amid continuous political instability, Said Mohamed Djohar saw his vision and legitimacy to carry out the transition process sanctioned after he won the 1990 multiparty presidential elections. In 1991, domestic participants of the Opposition Union met former presidential candidate Mohamed Taki in Paris to discuss the formation of an interim government and the organisation of a national conference. This conference, organised by Djohar, lasted from January to April 1992 and involved over twenty political parties, most of which were weak, centralised in the party leader and essentially regionalist (Hassan 2009; Ali, Roubani, and Said 2011). The more polarising issues concerned Udzima's dominance and the fact that it mainly represented the interests of the island of Anjouan. On the other hand, the Mohelians and most of the opposition parties demanded more inter-island institutional equilibrium, namely delocalisation of ministries, equitable distribution of high state functions at federal level, reinforcement of institutions at the island-level and an equal share of the State budget (Mohamed 2001, 204; Mohadji $2005,175)$. The conference produced a constitution draft which was approved by $75 \%$ of the voters who participated in the June 7 referendum.

Unlike the other cases in this study, no party law was enacted. The 1992 Constitution contained only minimal prescriptions intended to safeguard inter-island equilibria: 'Political parties (...) form and exercise their activity freely in respect of unity and national sovereignty, territorial integrity, democracy and balance between the islands' (Article 4). Although the Constitution called for the creation of a party law establishing the conditions for parties to register and provisions for public funding (Article 4), this was only recently enacted (in 2013). The successive constitutional revisions only provided minimal prescriptions for party formation which were eased over the years. ${ }^{6}$ The permissiveness of the law has meant the constant proliferation of political parties with a short life span.

The 1992 constitution had several innovations and many gains for the Mohelians with regards the institutional equilibria. The new constitution replaced presidentialism with semi-presidentialism, and instituted that the President could be elected for a maximum of two 5-year terms. It created a new bicameral parliament (15 Senate seats and 42 National Assembly seats), governors for all three islands and local government or island councils (Lucas 1992, 6; Mohamed 2001, 203-258). Members of the Senate (5 per island) were to be indirectly elected by the electoral colleges set on each island while Members of National Assembly were directly elected through plurality vote in single 
member districts. This means that the most voted candidate in each district wins the seat. This decision is contrary to the expectation that, in a multiparty configuration, the parties tend to prefer larger district magnitudes. In this case, the decision to keep the same formula that had been in place since 1961 can be seen as a way of avoiding further uncertainty in election outcomes.

\subsection{São Tomé and Príncipe}

Political reforms started from the mid-1980s in response to pressures from regime reformers and economic turmoil (Branco and Varela 1998, 52). Under the leadership of Manuel Pinto de Costa, the MLSTP launched the 'Politics of Citizen Engagement' aimed at promoting the active participation of citizens and civil society in decision making processes. The intended reforms opened deep divisions in the party's central committee, which Pinto de Costa sought to overcome by launching a national conference in 1989. However, it was unclear how broad the conference should be and whether its decisions were legally binding. It was finally decided - as Pinto da Costa wanted - that the conference participants would comprise members of the MLSTP in addition to individuals invited by the President. The conference was being prepared by the Reflection Group (Grupo de Reflexão - GR), which was made up mainly of regime reformers and counsellors to the President (Branco and Varela 1998, 66). The three days of congress (3-6 December) were marked by open and direct conversation, the likes of which had never been seen in the history of the country. The draft constitution was approved and then sanctioned in a constitutional referendum in which the people voted overwhelmingly for multipartyism. At a joint session on March 28 1990, the central committee of the MLSTP and the Popular National Assembly unanimously approved the new democratic constitution (Seibert 1999, 176).

The party law (Law 8/90) was enacted in September 1990, four months before the 1991 parliamentary elections. Given the more open process of political transition, the party formation process was easier than in Cabo Verde for instance. Legalising a party requires 250 signatures, programme, symbol and acronym (Article 9). But unlike Cabo Verde, residency is not a requirement and the Supreme Court's deliberation is issued within two weeks (Article 9). Parties were given access to indirect and direct state funding and to fiscal benefits to complement the funds collected via members' fees and other activities (Article 27). This law created conditions for the legalisation of three new political parties ahead of the 1991 elections: PCD-GR (which absorbed the GR), CODO and FDC (Sanches 2017).

In the final phase of the transition process, these parties released a joint declaration in which they accused the MLSTP/PSD of deliberately delaying the democratisation process. They further denounced what they considered excessive centralisation of decision making in the party and wanted to have a say in all decisions relevant for democratisation. More specifically, they demanded the creation of a 'National concerted council to discuss the timetable of the elections and the electoral laws, as well as the replacement of the people in charge of those state organs which might interfere in the political process, such as the local media and the supreme court' (Seibert 1999, 182).

The MLSTP-led conference maintained the PR electoral system for the parliamentary elections and established that both parties and independent candidates could run in 
the elections. The PR formula is applied in multimember constituencies with five out of seven districts electing more than five seats (Sanches 2017). These rules create stronger incentives for newcomers and confirm the prediction that multiparty configurations will tend to prefer PR and larger district magnitudes. As in Cabo Verde, the party elites opted for a semi-presidential constitution but in which the President has stronger powers in the areas of cabinet formation and dismissal (Seibert 2009). The reason why the key political actors opted for this design lies to some extent in the very nature of political transitions. In fact, the far reaching executive power of the president had been tailormade for Pinto da Costa, who was not content with mere representative functions. When the constitution was being drafted, neither he nor his party had any doubt that he would be the country's first democratically elected president, but he eventually withdrew from the elections (Seibert 1999, 177).

\subsection{Seychelles}

On 4 December 1991, President France-Albert René announced a return to the multiparty system at an Extraordinary Congress of the SPPF, and the constitution was subsequently amended to allow the registration of political parties (Seychelles Nation ${ }^{7}$ ). This decision was the result of international pressure after René had passed a resolution in April 1991 stating that Seychelles would forever remain a one-party state (Baker 2008, 280).

The transition process involved the creation of a Constitutional Committee (CC) to draft the new Constitution, a referendum on the draft Constitution and general elections (Commonwealth Secretariat 1992). Elections for the CC were held between 23 and 26 July 1992, but only two out of eight competing parties exceeded the $5 \%$ threshold: the SPPF $(58.4 \%$, 14 representatives) and the DP (33.7\%, 8 representatives). The CC began working on the draft on 27 August but the two rival parties were unable to reach a consensus. DP delegates eventually abandoned the CC and joined six other parties to create the United Opposition which campaigned for the 'no' vote on the grounds that they considered the Constitution undemocratic. Their complaints included the limitation of candidacy to presidential candidates, the absence of a limit on presidential terms, and the appointment of members of the national assembly on the basis of the results of presidential elections. The first referendum failed to pass with $53.7 \%$ voting in favour and $44.6 \%$ against. The CC resumed work on 11 January 1993 to prepare a fresh draft, imbued with a new spirit of cooperation and compromise with smaller political parties, churches and members of the public taking part in the meetings. The consensus draft was agreed on 7 May 1993 and a referendum called for 15-18 June. Although several parties campaigned against the draft, the DP and SPPF successfully campaigned for its approval, winning with $73.9 \%$ of the votes.

Some issues were resolved ahead of the 1993 Presidential and National elections. All parties had accepted that the voters' registration list was credible and as accurate as possible. The government had reassessed the question of funding of political parties and had decided to allocate a fixed amount for this purpose to be divided among all parties taking part in the elections, proportionate to the support each received in the July 1992 election (Commonwealth Secretariat 1993). The party law (Political parties Registration and Regulation Act -Cap. 173, Act 19 of 1991) stipulates that a political party must consist of no less than 100 registered members. Party members must be over 17 and be a Seychelles citizen 
and resident (Article 5). Applications for registration must also include copies of the constitution and rules of the party, information on its main office and other details required by the Commissioner (Article 5). A party may be refused registration if the application does not satisfy the terms of the Act, namely if their aims further discrimination on the grounds of race, religion or colour, advocate violent or illegal political changes or the secession of any part of the Republic (Article 7).

The new constitution reinstated a mixed legislative system (plurality and PR with Hare quota) with 25 seats elected in single-member constituencies but with a maximum of 10 additional seats distributed among parties that receive more than $10 \%$ of the votes cast (Poupko 2017, 330). This system was endorsed by the incumbent SPPF/PL for reasons that seem both logical and strategic. First, plurality tends to produce absolute winners. Candidates run in single-member constituencies and it is usually the largest dominant party that takes the seat. Second, the $10 \%$ threshold further accentuates a winnerstake-all scenario as smaller parties may struggle to reach that mark.

As for the choice of the executive system, the SPPF/PL supported the outgoing presidential system and the DP proposed a shift to semi-presidentialism. As the incumbent party, the SPPF/PL's preference was to maintain the institutional devices inherited from the previous authoritarian regime. This position can be perceived as a way of minimising the risks and uncertainties of an institutional shift. The presidential system was ultimately chosen and validated in the 1993 constitutional referendum by $75 \%$ of the vote cast.

\subsection{Institutional choices and pathways to party system development}

The preceding analysis highlighted the different timings and dynamics of democratic transition in each country and the institutional choices made during this critical juncture (see Table 1). In Cabo Verde and São Tomé and Príncipe, initial liberalisation reforms were launched in the mid-1980s as part of a strategic move by the incumbent authoritarian elites - PAICV and MLSTP - to demobilise regime reformers. The PAICV controlled the initial stages of the liberalisation agenda but the MpD eventually levelled the playing field and participated in the institutional decision making leading to the first elections

Table 1. Transition modes and institutional choices.

\begin{tabular}{|c|c|c|c|c|}
\hline & Cabo Verde & Comoros & São Tomé and Príncipe & Seychelles \\
\hline Transition mechanism & Pact between elites & $\begin{array}{l}\text { Party national } \\
\text { conference }\end{array}$ & $\begin{array}{l}\text { Party national } \\
\text { conference }\end{array}$ & $\begin{array}{l}\text { Elected } \\
\text { constitutional } \\
\text { committee }\end{array}$ \\
\hline $\begin{array}{l}\text { Who participated in } \\
\text { the negotiations }\end{array}$ & $\begin{array}{l}\text { Incumbent and main } \\
\text { opposition party }\end{array}$ & $\begin{array}{l}\text { Incumbent party, over } \\
\text { twenty parties and } \\
\text { CSOs* }\end{array}$ & $\begin{array}{l}\text { Incumbent party, } \\
\text { regime reformers, } \\
\text { individuals }\end{array}$ & $\begin{array}{l}\text { Incumbent and } \\
\text { main opposition } \\
\text { party }^{* *}\end{array}$ \\
\hline $\begin{array}{l}\text { Number of parties/ } \\
\text { alliances who } \\
\text { competed in the first } \\
\text { election }\end{array}$ & 2 & 22 & 4 & 3 \\
\hline \multicolumn{5}{|c|}{ Nature of the institutions chosen during transition } \\
\hline Type of party law & Restrictive & Permissive & Permissive & Restrictive \\
\hline Electoral system & PR formula & Plurality formula & PR formula & Mixed formula \\
\hline $\begin{array}{l}\text { Structure of executive } \\
\text { powers }\end{array}$ & Semipresidential & Semipresidential & Semipresidential & Presidential \\
\hline
\end{tabular}


in 1991. In São Tomé and Príncipe, the MLSTP, and particularly the incumbent President Manuel Pinto da Costa centralised most decisions and used ad hoc solutions - a national conference - to overcome internal dissidence, but the regime reformers managed to have a say in the institutional choices. In the Comoros and the Seychelles, the most signficant reforms were introduced in the early 1990s at a time of stronger pressure from the international community, just a few years before the first multiparty elections in 1992 and 1993 respectively. Under the leadership of René and the SPPF, the Seychellois constitution was amended to allow party formation. Then the reforms were discussed in an elected CC comprising members of the SPPF and the DP. Finally, in the Comoros the incumbent President Said Mohamed Djohar, from the Udzima, called for the organisation of a national conference, in which over twenty political parties participated. How did the institutional decisions made at this point structured the competition over time?

More restrictive party laws were chosen in Cabo Verde and Seychelles where parties were required to submit a more complete 'dossier' and appeared to be subject to greater scrutiny. This is particularly so in the Seychelles where the law makes more frequent mention of punitive mechanisms. It is easier to form political parties in the Comoros and São Tomé and Príncipe and the minimal regulations in the former entailed a constant proliferation of parties and successive episodes of parties merging and disappearing. This is further accentuated by the very nature of party formations, which are largely personalistic and regionalist despite the fact that the constitution prohibits regional, ethnic and religious parties (Article 7).

These different regulations had important effects on the structuring of party systems. In Seychelles and Cabo Verde, they created higher barriers for party formation and shielded the interests of those who negotiated the transition, whereas in the Comoros and São Tomé and Príncipe they eased party proliferation. Party laws mattered during the transition and beyond as no significant change in the rules has been approved over time. The exception is the Comoros, where a party law was finally passed in 2013 (Law No. $13010 \mathrm{AU}$ ) but the overall regulations remain non-restrictive. ${ }^{8}$

In terms of the electoral system, the uncertainty of political transition led both incumbent and newcomers to choose on the basis of their future odds - a share of seats or an absolute win. The PR formula in Cabo Verde is applied mostly in small-size constituencies that elect a maximum of four seats on average and it therefore ends up favouring the larger parties against newcomers. The same can be said about Seychelles' mixed formula that elects $75 \%$ of the parliamentary seats in single member constituencies and includes a $10 \%$ election threshold. This benefits the larger and established parties: the MpD and the PAICV in Cabo Verde, and the SPPF/PL in the Seychelles. Recent changes in the electoral law in Cabo Verde (in 2010) only accentuated the dominance of the two main parties. In fact, the creation of island-level electoral districts forces smaller parties to invest in nationwide organisations; this is costly and likely to favour the country's only two nationwide parties: PAICV and MpD. In the Comoros, the continuous political instability made interparty competition highly centrifugal. Contrary to Seychelles where plurality leads to higher levels of stability, in the Comoros the same formula exacerbates an endemic polarisation driven by inter-island contentions on the structure of the federal state and the extent of presidential powers. Indeed, plurality formulas fail to produce reductive effects on a national scale if there is great subnational or cross-constituency dispersion of issues which cannot be represented by two major parties (Sartori 2003). In São 
Tomé and Príncipe, the choice of a PR system in a context of multiple competing parties was instrumental to the immediate alternation in power and in future elections.

In terms of executive system, all countries opted for semi-presidentialism except the Seychelles which remained presidential. This was an important victory for incumbent President René and his SPPF over the DP, the main negotiating partner; and structured the competition over time. After winning the founding general elections, the SPPF remained the dominant party in successive polls controlling the presidency and the legislature simultaneously. Change only came recently with the SPPF electing the president in 2015 and LDS winning the 2016 parliamentary elections. In Cabo Verde, the party elites disagreed on the extent of presidential powers but they eventually committed to a semi-presidential constitution. One year after the 1991 polls, a constitutional amendment was approved to reduce the presidential power to dissolve parliament and dismiss the cabinet and also to balance the relation between the President and Prime Minister (Neto Octavio and Lobo 2014, 446). Over time the PAICV and MpD have been able to form singleparty cabinets with wide parliamentary support. There have been successive episodes of unified government since the founding multiparty elections. The only episode of cohabitation was between 2011 and 2016 when the PAICV had a parliamentary majority with the $\mathrm{MpD}$ in the presidency.

Comoros and São Tomé and Príncipe also opted for semi-presidentialism, but with a constitutionally stronger president in the areas of cabinet formation and dismissal. The reasons behind this choice lie in the very nature of each country's political transition. Both these countries experienced more polarised transition processes during which several new political parties emerged. Whereas the founding multiparty elections in Cabo Verde and Seychelles were contested by very few parties, more parties went to the polls and gained representation in São Tomé and Príncipe and Comoros. Consequently, partial alternation in power and coalition cabinets have been more frequent in these two cases. The option for a strong president can thus be seen as a way of overcoming governing instability. ${ }^{9}$

In sum, more stable party systems emerged in Cabo Verde and Seychelles where the elites managed to control the transition and select the most favourable intuitions. Higher levels of stability have been sustained by more restrictive party laws, electoral laws that benefit the larger parties, and more stable intra-executive relations. In contrast, Comoros and São Tomé and Príncipe have less stable party systems. The party laws are more permissive, the electoral formulas encourage representation of smaller parties, and the choice for stronger presidents in a context with multiple competing parties has further exacerbated political instability.

\section{Conclusion}

Focusing on the political experiences of four small African islands - Cabo Verde, Comoros São Tomé and Príncipe and Seychelles - this article has explored the ways in which institutional choices made during the democratic transition influenced different trajectories of party system development. The selection of four similar cases sought to control rival explanations, and to isolate the variable of interest (institutional choice). The in-depth analysis began by tracing the choices made during transition, a critical juncture of institutional crafting, and then related those choices with the different pathways of party systems 
stability. It thus aimed to provide a link between institutional choices and their consequences by highlighting the role of agency and strategic decisions of party elites to reduce electoral uncertainty.

Overall, two main findings merit highlight. First, as elsewhere across the continent, party systems in these four cases vary substantially in their degree of stabilisation. Across successive rounds of elections, Cabo Verde and Seychelles have experienced fewer episodes of alternation in power and of high volatility than Comoros and São Tomé and Príncipe. Secondly, strategic choices of party laws, electoral laws and executive systems helped structure the political competition beyond the critical juncture of democratic transition. In Cabo Verde and Seychelles, the transition negotiators kept the electoral rules that imposed greater constraints on newcomers and adopted party laws that were more protective of their interests. Moreover, the definition of presidential powers envisaged the goal of cabinet stability. Over the years, there has been little change in these institutional rules, thus underlining their critical impact on the prospects of stabilisation. In the Comoros and in São Tomé and Príncipe, the transition was held under the auspices of national conferences which could be attended by different political groups, individuals, and even civil society organisations, particularly in the case of Comoros. The electoral rules and the more flexible party laws introduced at this stage contributed to a constant proliferation of parties, most of which personalistic (but also regionalist as the case of Comoros illustrates). In these two cases, the president is often the 'tie breaker', which makes presidential elections vital for cabinet survival. The nascent party systems in Comoros and in São Tomé and Príncipe ended up being more open, with more rotation in power and more unpredictable results.

The key lesson to be drawn from this comparative exercise is that successful stabilisation depends on the party elites' ability to craft institutional rules that can protect them from uncertainty in future interactions. Institutional rules are not neutral; they can decide the number of parties that are durable and have a chance of forming government. Once these rules are in place, parties are unwilling to change them and the cases herein demonstrate the high cost of institutional change for party elites (only Comoros and São Tomé and Príncipe made significant changes, and these addressed the executive system). This study contributes to the literature on party system development in Africa in two directions. On the one hand, it highlights the relevance of democratic transitions. While most studies have convincingly demonstrated the relevance of authoritarian legacies for party system development, it remains unclear which decisions were made during the transition and how this structured the competition over time. On the other hand, it shows that agency matters during the transition and beyond because, once in place, the institutional rules tend to be preserved in continuous rounds of elections. Future work is needed to clarify the nature of regime transitions in Africa and their long term impacts in political competition; and to explore the role of party agency in reducing uncertainty in future elections. To the extent that this discussion can be extrapolated to the democratisation debate, it suggests that party agency is crucial for democratic development.

\section{Notes}

1. For instance, since 1991, São Tomé and Príncipe has experienced several episodes of cabinet dismissal and two military coups $(1995,2003)$. Since 1993, Comoros has recorded six coups or 
plots against the government $(1995,1999,2001,2003$, and 2013) and has faced secessionist threats from the Mohéli Island.

2. However, this kind of methodological design tends to produce deterministic assumptions. For further discussions see Frendreis (1983) and Lieberson (1991).

3. The MLSTP renamed MLSTP/Partido Social Democrata in 1990.

4. The União dos Povos das Ilhas de Cabo Verde (UPICV) based in Senegal, and União Cabo-Verdiana Independente e Democrata (UCID) active in the United States and the Netherlands.

5. This view has been conveyed by political elites of both parties, interviewed during field work in January.

6. For example, under Article 5 of the 1996 constitution (http://mjp.univ-perp.fr/constit/km1996. $\mathrm{htm}$ ), a party could be dissolved if it failed to elect two candidates per island but this requirement was removed in the 2001 revision (http://mjp.univ-perp.fr/constit/km2001.htm).

7. Chronology of events available at: http://www.nation.sc/article.html?id=254530 (accessed on $15 / 06 / 2018)$.

8. Registering requires a minimum of 20 signatures in each constituency and a dossier including a statement from one of the founding members, founding constitutions, members' details, party name, symbol and address. The reply is communicated immediately or via mail within two months (Chapter I).

9. In Comoros the president's powers have been increased in successive constitutional revisions (2001 and 2009) while in São Tomé and Príncipe they were curtailed in 2003, (Seibert 2016). In both cases politics remains more unpredictable than in the other cases.

\section{Acknowledgement}

The author would like to thank the reviewers for their careful reading and insightful comments. This work has been supported by the Portuguese Foundation for Science and Technology through the project CEECIND/02527/2017 and the PhD scholarship SFRH/BD/145649/2019.

\section{Disclosure statement}

No potential conflict of interest was reported by the author(s).

\section{Funding}

This work has been supported by the Portuguese Foundation for Science and Technology through the project CEECIND/02527/2017 and the PhD scholarship SFRH/BD/145649/2019. Fundação para a Ciência e a Tecnologia.

\section{Notes on contributor}

Edalina Rodrigues Sanches is a Research Fellow in Political Science at the Institute of Social Sciences University of Lisbon, and a Guest Lecturer at ISCTE-Lisbon University Institute. Her research interests comprise democratisation, elections, political parties and party systems, with a focus on Africa. Her latest book is Party Systems in Young Democracies: Varieties of institutionalization in Sub-Saharan Africa (Routledge, 2018).

\section{ORCID}

Edalina Rodrigues Sanches (10) http://orcid.org/0000-0001-6007-3680 


\section{References}

Ali, Damir Bem, Kaambi Roubani, and Mahamoudou Said. 2011. Analyse des potentiels et dynamiques de conflits et des facteurs structurels qui minent la cohesion sociale en Union des Comores. UNDP.

Anckar, Carsten. 2008. "Size, Islandness, and Democracy: A Global Comparison." International Political Science Review 29: 433-459.

Baker, Bruce. 2008. "Seychelles: Democratising in the Shadows of the Past." Journal of Contemporary African Studies 26 (3): 279-293.

Banks, Arthur S., Thomas C. Muller, and William R. Overstreet. 2007. Political Handbook of Africa 2007. Washington, DC: CQ Press.

Basedau, Matthias. 2007. "Do Party Systems Matter for Democracy? A Comparative Study of 28 SubSaharan Countries." In Votes, Money and Violence Political Parties and Elections in Sub-Saharan Africa, edited by Matthias Basedau, Gero Erdmann, and Andreas Mehler, 105-143. Uppsala, Sweden: Nordiska Afrikainstitutet.

Bogaards, Matthijs. 2004. "Counting Parties and Identifying Dominant Party Systems in Africa." European Journal of Political Research 43: 173-197.

Branco, Rafael, and Afonso Varela. 1998. Os caminhos da democracia: São Tomé e Príncipe. Amadora: selfpublishing.

Briguglio, Lino et al. 2005. "Conceptualising and Measuring Economic Resilience." In Pacific Islands Regional Integration and Governance, edited by Satish Chand, 26-49. Canberra: ANU Press.

Casal Bértoa, Fernando. 2018. "The Three Waves of Party System Institutionalisation Studies: A Multior Uni-Dimensional Concept?" Political Studies Review 16 (1): 60-72.

Casal Bértoa, Fernando, and Zsolt Enyedi. 2016. "Party System Closure and Openness: Conceptualization, Operationalization and Validation." Party Politics 22 (3): 265-277.

Clemente-Kersten, Ana Catarina. 1999. "Cape Verde." In Elections in Africa. A Data Handbook, edited by Dieter Nohlen, Michael Krennerich, and Bernhard Thibaut, 189-204. New York: Oxford University Press.

Colomer, Josep M. 2001. "Disequilibrium Institutions and Pluralist Democracy." Journal of Theoretical Politics 13 (3): 235-247.

Colomer, Josep M. 2005. "It's the Parties That Choose Electoral Systems (or Duverger's Laws Upside Down)." Political Studies 53: 1-21.

Commonwealth Secretariat. 1992. Elections to the Constitutional Commission in Seychelles 23-26 July 1992. The Report pf the Commonwealth Observer Group.

Commonwealth Secretariat. 1993. The Presidential and National Assembly Elections in Seychelles 20-23 July 1993. The Report pf the Commonwealth Observer Group.

Costa, Daniel. 2001. "O Semi-presidencialismo em Cabo Verde (1991-2000)." Master Thesis. Instituto Universitário de Pesquisas do Rio de Janeiro, Rio de Janeiro.

Cotta, Maurizio. 1996. "Structuring the New Party Systems After the Dictatorship: Coalitions, Alliances, Fusions and Splits During the Transition and Post-Transition Stages." In Stabilising Fragile Democracies: Comparing New Party Systems in Southern and Eastern Europe, edited by Geoffrey Pridham, and Paul G. Lewis, 69-99. London and New York: Routledge.

Duverger, Maurice. 1959. Political Parties: Their Organization and Activity in the Modern State. London: Methuen \& Co.

Elgie, Robert. 2011. Semi-Presidentialism Sub-Types and Democratic Performance. Oxford: Oxford University Press.

Ferree, Karen E. 2010. "The Social Origins of Electoral Volatility in Africa." British Journal of Political Science 40: 759-779.

Fleischhacker, Helga. 1999. "São Tomé and Príncipe." In Elections in Africa. A Data Handbook, edited by Dieter Nohlen, Michael Krennerich, and Bernhard Thibaut, 739-755. New York: Oxford University Press.

Frendreis, John P. 1983. "Explanations of Variation and Detection of Covariance: The Purpose and Logic of Comparative Analysis." Comparative Political Studies 16 (2): 255-272.

Goeke, Martin, and Christof Hartmann. 2011. "The Regulation of Party Switching in Africa." Journal of Contemporary African Studies 29 (3): 263-280. 
Hassan, Hamdy A. 2009. "The Comoros and the Crisis of Building a National State." Contemporary Arab Affairs 2 (2): 229-239.

Hogan, John, and David Doyle. 2009. "A Comparative Framework: How Broadly Applicable is a "Rigorous" Critical Junctures Framework?" Acta Politica 44 (2): 211-240.

Kuenzi, Michelle, et al. 2017. "The Economic Determinants Of electoral Volatility in Africa." Party Politics. First Published September 19, 2017.

Kuenzi, Michelle, and Gina Lambright. 2001. "Party System Institutionalization in 30 African Countries." Party Politics 7 (4): 437-468.

Laakso, Markku, and Rein Taagepera. 1979. "The 'Effective' Number of Parties: A Measure with Application to West Europe." Comparative Political Studies 12 (1): 3-27.

LeBas, Adrienne. 2011. From Protest to Parties. Party-Building and Democratization in Africa. Oxford: Oxford University Press.

Lieberson, Stanley. 1991. "Small N's and Big Conclusions: An Examination of the Reasoning in Comparative Studies Based on a Small Number of Cases." Social Forces 70 (2): 307-320.

Lijphart, Arend. 1994. Electoral Systems and Party Systems: A Study of Twenty-Seven Democracies, 19451990. New York: Oxford University Press.

Lindberg, Staffan I. 2005. "Consequences of Electoral Systems in Africa: A Preliminary Inquiry." Electoral Studies 24 (1): 41-64.

Lindberg, Staffan I. 2007. "Institutionalization of Party Systems? Stability and Fluidity among Legislative Parties in Africa's Democracies." Government and Opposition 42 (2): 215-241.

Linz, Juan J. 1990. "The Perils of Presidentialism." Journal of Democracy 1 (1): 51-69.

Lucas, Eugenie A. 1992. "Democratic Transition in the Islands: A Final Report on the IFES Civic Education Project in Comoros." International Foundation for Electoral systems. http://pdf.usaid. gov/pdf_docs/PDABF921.pdf.

Lupu, Noam, and Rachel Beatty Riedl. 2013. "Political Parties and Uncertainty in Developing Democracies." Comparative Political Studies 46 (11): 1339-1365.

Mainwaring, Scott. 1999. Rethinking Party Systems in the Third Wave of Democratization: The Case of Brazil. Standford, California: Stanford University Press.

Mainwaring, Scott. 2018. "Introduction" In Party System in Latin America, edited by Scott Mainwaring, 1-16. Cambridge: Cambridge University Press.

Mainwaring, Scott, and Timothy R. Scully. 1995. Building Democratic Institutions: Party Systems in Latin America. Standford, California: Stanford University Press.

Mair, Peter. 1996. "Comparing Party Systems." In Comparing Democracies: Elections and Voting in Global Perspectives, edited by Lawrence LeDuc, Richard G. Niemi, and Pippa Norris, 83-106. London: Sage Publications.

Mohadji, Faissoili Ben. 2005. "Comores (Union des Comores)." In Guide des Pays Fédérés 2005, edited by Ann L. Griffiths, and Karl Nerenberg, 173-187. Quebec: McGill-Queen's University Press.

Mohamed, Abdelaziz Riziki. 2001. Comores: Les Institutions D'un Etat Mort-Né. Paris: Editions L'Harmattan.

Neto Octavio, Amorim, and Marina Costa Lobo. 2014. "Semi-presidentialism in Lusophone Countries: Diffusion and Operation." Democratization 21 (3): 434-457.

Norris, P., and M. Grömping. 2019. Perceptions of electoral integrity, (PEI-7.0). doi:10.7910/DVN/ PDYRWL

O'Donnell, Guillermo, and Philippe Schmitter. 1986. Transitions From Authoritarian Rule: Tentative Conclusions About Uncertain Democracies. Baltimore: Johns Hopkins University Press.

Ojo, Akinloye. 2016. "Comoros, Federal Islamic Republic of the." In Africa: An Encyclopedia of Culture and Society, edited by Toyin Falola, and Daniel Jean-Jacques, 254-283. California: ABC-CLIO, LLC.

Osei, Anja. 2013. "Party System Institutionalization in Ghana and Senegal." Journal of Asian and African Studies 48 (5): 577-593. doi:10.1177/0021909612465720.

Pedersen, Mogens N. 1983. "Western European Party Systems: Continuity and Change." In Changing Patterns of Electoral Volatility in European Party Systems: Explorations in Explanation, edited by Hans Daalder, and Peter Mair, 29-66. Beverly Hills, CA, London: Sage.

Poupko, Eliezer S. 2017. "An Exploratory Study of Constitutional Design in Three Island States: Seychelles, Comoros, and Mauritius." Journal of Contemporary African Studies 35 (3): 324-348. 
Riedl, Rachell Beatty. 2014. Authoritarian Origins of Democratic Party Systems in Africa. New York: Cambridge University Press.

Salih, Mohamed A. M., and Per Nordlund. 2007. Political Parties in Africa: Challenges for Sustained Multiparty Democracy. Stockholm, Sweden: International IDEA.

Sanches, Edalina Rodrigues. 2017. "Construindo uma democracia de partidos: Cabo Verde e São Tomé e Príncipe em perspetiva comparada (1991-2016)." In Democratização, memória e justiça de transição nos países lusófonos, edited by M. P. Araújo and A. C. Pinto, 164-194. Rio de Janeiro: Universidade de Pernambuco.

Sanches, Edalina Rodrigues. 2018. Party Systems in Young Democracies: Varieties of Institutionalization in Sub-Saharan Africa. New York: Routledge.

Sartori, Giovanni. 1976. Parties and Party Systems: A Framework for Analysis. Cambridge: Cambridge University Press.

Sartori, Giovanni. 2003. "The Influence of Electoral Systems: Faulty Laws or Faulty Method?" In Electoral Laws and Their Political Consequences, edited by Bernard Grofman, and Arend Lijphart, 43-68. New York: Agathon Press.

Schaefer, Richard T. 2008. Encyclopedia of Race, Ethnicity, and Society, Volume 1. Thousand Oaks, California: Sage Publications.

Seibert, Gerhard. 1999. Comrades, Clients, and Cousins: Colonialism, Socialism, and Democratization in São Tomé and Príncipe. Leiden \& Boston: Brill.

Seibert, Gerhard. 2009. "Instabilidade Política e Revisão Constitucional em São Tomé e Príncipe." In Marina Costa Lobo and Octavio Amorim Neto, edited by O Semipresidencialismo nos Países de Língua Portuguesa, 201-230. Lisboa: Imprensa de Ciências Sociais.

Seibert, Gerhard. 2016. "São Tomé and Príncipe 1975-2015: Politics and Economy in a Former Plantation Colony." Estudos Ibero-Americanos 42 (3): 987-1012.

Thibaut, Bernhard. 1999a. "Comoros." In Elections in Africa. A Data Handbook, edited by Dieter Nohlen, Michael Krennerich, and Bernhard Thibaut, 243-259. New York: Oxford University Press.

Thibaut, Bernhard. 1999b. "Seychelles." In Elections in Africa. A Data Handbook, edited by Dieter Nohlen, Michael Krennerich, and Bernhard Thibaut, 775-788. New York: Oxford University Press. van Cranenburgh, Oda. 2003. "Power and Competition: The Institutional Context of African MultiParty Politics." In African Political Parties: Evolution, Institutionalisation and Governance, edited by Mohamed A. M. Salih, 188-206. London: Pluto Press.

van de Walle, Nicolas. 2003. "Presidentialism and Clientelism in Africa's Emerging Party Systems." The Journal of Modern African Studies 41 (2): 297-321.

Veenendaal, Wouter P., and Jack Corbett. 2015. "Why Small States Offer Important Answers to Large Questions." Comparative Political Studies 48 (4): 527-549.

Weghorst, Keith R., and Michael Bernhard. 2014. "From Formlessness to Structure? The Institutionalization of Competitive Party Systems in Africa." Comparative Political Studies 47 (12): 1707-1737. 